\title{
Rheumatoid arthritis: treatment with azathioprine (IMURAN (R)). Clinical side-effects and laboratory abnormalities
}

\author{
J K WHISNANT AND J PELKEY \\ From the Immunology Section, Department of Clinical Investigation, Burroughs Wellcome Co, USA
}

SUMMARY A retrospective review of the literature has been carried out to determine laboratory abnormalities occurring in patients with rheumatoid arthritis (RA) treated with azathioprine, in order to establish a profile for this agent in the treatment of this disease.

A total of 542 patients in 24 studies, reported in the literature, were given a range of doses of azathioprine for up to four years. Fifteen percent of patients were withdrawn because of toxicity. The two major toxic effects were gastrointestinal symptoms and alteration in blood counts. Clinically significant leucopenia (less than $2500 / \mathrm{mm}^{3}$ ) occurred in 14 of the total of 93 patients reported to have developed leucopenia. Some adverse reactions, which would have been expected from the use of azathioprine in other diseases, were uncommon, namely significant infections, hepatotoxicity and pancreatitis. Adverse experience with azathioprine in rheumatoid arthritis compares well with other slow-acting, or disease modifying, drugs.

Immunosuppressive therapy of rheumatoid arthritis (RA) with the thiopurine azathioprine (IMURAN (R)) has been reported since 1965 . The initial experiences with this drug stimulated some enthusiasm and there were 11 publications in the period 1965-1970. 1522455172129143150206207212 In the next five years (1971-1975), the problems of significant haematological toxicity and the possibility of malignancy in renal transplantation patients treated with azathioprine caused concern, so that less investigation and interest was evident during these years. Major studies were reported again in 1976-1977 and some of these, especially those by Balken, ${ }^{12}$ Berry et al, ${ }^{18}$ Dwosh et al ${ }^{56}$ and Goebel et $a l,{ }^{80}$ stimulated re-evaluation of the place of azathioprine in the treatment of rheumatoid arthritis. A total of 24 studies published in the English litera- ture, or available in translation, over an 11-year period is now available for review to assess the composite adverse experience with azathioprine in this non-transplant disease category.

\section{Methods of review}

A composite azathioprine literature listing, including computerised reference banks, was first used to establish a primary literature data base. There are, as always, multiple citations which mention azathioprine for RA but which give no clinical data or patient

TABLE 1 Twenty-four articles reviewed with year of publication, number of patients treated with azathioprine and concomitant therapy

\begin{tabular}{|c|c|c|c|}
\hline Reference & Year & $\begin{array}{l}\text { Azathio- } \\
\text { prine }\end{array}$ & Other therapy \\
\hline Apostoloff $e t a l^{7}$ & 1974 & 9 & \\
\hline Balken $^{12}$ & 1976 & 41 & $\begin{array}{l}\text { Steroids, analgesics, } \\
\text { antirheumatic agents }\end{array}$ \\
\hline Barnikol and Vorlaender ${ }^{15}$ & 1967 & 9 & Antirheumatic \\
\hline${ }^{*}$ Berry et al ${ }^{18}$ & 1976 & 33 & $\begin{array}{l}\text { Steroids, anti- } \\
\text { inflammatory agents }\end{array}$ \\
\hline Bruckner et $a l^{22}$ & 1969 & 6 & Steroids \\
\hline${ }^{*}$ Cade $e t a l^{25}$ & 1976 & 18 & Salicylates, steroids (1) \\
\hline${ }^{*}$ Currey et $a l^{38}$ & 1974 & 44 & $\begin{array}{l}\text { Corticosteroids, aspirin, } \\
\text { paracetamol }\end{array}$ \\
\hline Denman et $a l^{45}$ & 1970 & 5 & Prednisone \\
\hline${ }^{*}$ Dixon et $a l^{49}$ & 1971 & 14 & \\
\hline Dodson and Bennett ${ }^{51}$ & 1969 & 23 & \\
\hline${ }^{*}$ Dwosh et al ${ }^{56}$ & 1977 & 11 & Steroids (1) \\
\hline Fricke and Deicher ${ }^{72}$ & 1969 & 8 & $\begin{array}{l}\text { 6-methyl-prednisolone, } \\
\text { phenylbutazone, } \\
\text { indomethacin }\end{array}$ \\
\hline${ }^{*}$ Goebel $e t a l^{80}$ & 1976 & 34 & Aspirin, indomethacin \\
\hline Khanna and Woodbury ${ }^{114}$ & 1973 & 21 & \\
\hline Levy et al ${ }^{123}$ & 1975 & 49 & Salicylates, steroids \\
\hline Lorenzen et al ${ }^{129}$ & 1969 & 9 & \\
\hline Mason et al ${ }^{143}$ & 1969 & 27 & Steroids, paracetamol \\
\hline Moens and Brocteur ${ }^{150}$ & 1965 & 11 & $\begin{array}{l}\text { Steroids, 6-methyl- } \\
\text { deltahydrocortisone, } \\
\text { actinomycin-C }\end{array}$ \\
\hline Pinals $^{177}$ & 1976 & 21 & Corticosteroids (17) \\
\hline Swannell and Coomes ${ }^{206}$ & 1969 & 9 & Steroids (9), ACTH (1) \\
\hline Swannell and Kersley ${ }^{207}$ & 1969 & 26 & Prednisolone \\
\hline Tausch et $a l^{212}$ & 1970 & 73 & Steroids (46) \\
\hline${ }^{*}$ Urowitz et al ${ }^{224}$ & 1973 & 17 & Salicylates \\
\hline *Urowitz et $a l^{22,5}$ & 1974 & 24 & Salicylates \\
\hline
\end{tabular}

*Controlled study. 
experiences, which were eliminated. A smaller, but significant, number of publications report fewer than five patients without comparison or control patient group information; these, too, were eliminated. The selected published studies included in this analysis are listed in table 1, with the numbers of patients and year of each publication. Some of the 24 studies were published more than once, but duplicate reporting of the same patient groups was consolidated in abstracting information. The authors' statements regarding diagnosis, or diagnostic criteria, were accepted. Patients included in these azathioprine studies were usually those with severe, disabling arthritis, unresponsive to conventional therapy. Careful attention was directed to eliminating the patients with diseases other than RA sometimes included in these reports.

All clinical toxicities and laboratory abnormalities included in each publication were tabulated. Summary profile sheets on each study were prepared, and these are available from the authors. It was not possible to impose a uniform grading system for severity of toxicities, except where specific haematological or other laboratory data were given. Results are given in terms of total percentage of patients with a specific toxicity. Particular attention was given to cases requiring withdrawal from treatment, to cases with life-threatening or fatal reactions and to toxicities occurring in control groups, where such were included (designated by asterisk in table 1). A detailed review of original patient records was conducted on four of the 24 studies: Urowitz et al, ${ }^{224}$ Urowitz et al ${ }^{225}$ Levy et al ${ }^{123}$ and Cade et al.$^{25}$

\section{Results}

From this review of the literature, 542 patients could be studied (table 1). The most important side-effect of this antimetabolite thiopurine is its effect on white cell production manifest by peripheral leucopenia. The total incidence of haematological toxicity is illustrated in fig 1 . Individual patient side-effects may have been multiple, and the percentage represented is the total for that individual toxicity. There were 142 haematological toxicity events reported in a total of 542 patients. Had all of these events occurred in separate patients, a total of $26 \%$ of patients might have been affected.

Leucopenia of any degree was mentioned in 93 $(17 \%)$ of the 542 patients. Of these 93 patients, actual leucocyte values were reported in 67; these are summarised in fig 1 . Fourteen patients were reported to have a leucopenia low enough to cause clinical risk
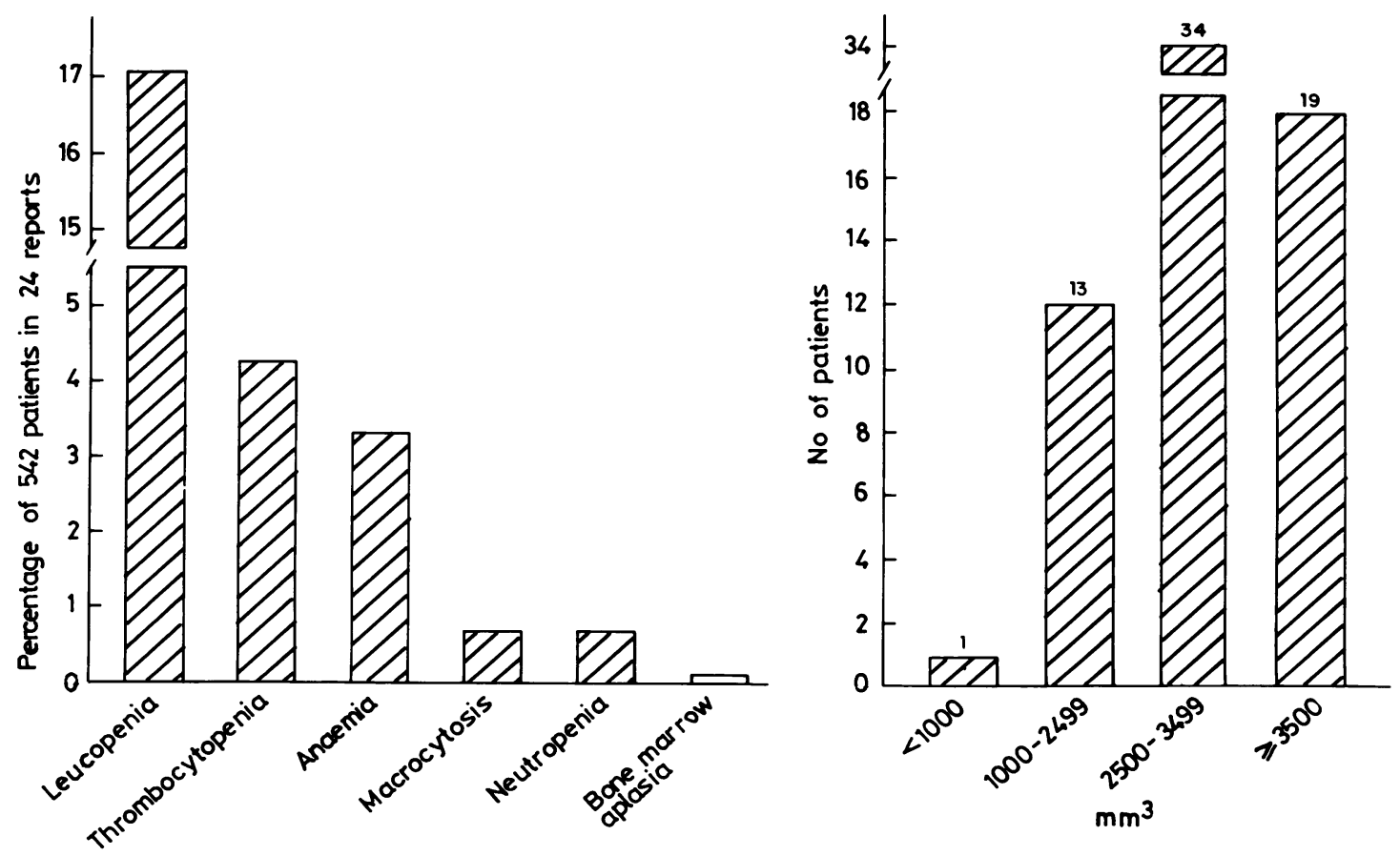

FIG 1 Incidence of haematological adverse effects reported in 24 published reports of 542 patients receiving azathioprine (left). No of cases with degree of leucopenia as reported in patients on whom data are available (right). 
(less than $2500 / \mathrm{mm}^{3}$ ). The majority of patients had white blood cell counts between 2500 and $3500 / \mathrm{mm}^{3}$, and an additional approximately $25 \%$ had counts above $3500 / \mathrm{mm}^{3}$. There were an additional four cases mentioned to have developed 'neutropenia', but the degree of neutropenia was not specified. Discontinuation of therapy or withdrawal from a study was uncommon as a result of haematological toxicity.

A review of the six studies published in 1976-1977 12 18255680177 shows an incidence of leucopenia of only $10 \%$.

The haematological data from 108 patients in the four studies reviewed in depth were similar to those

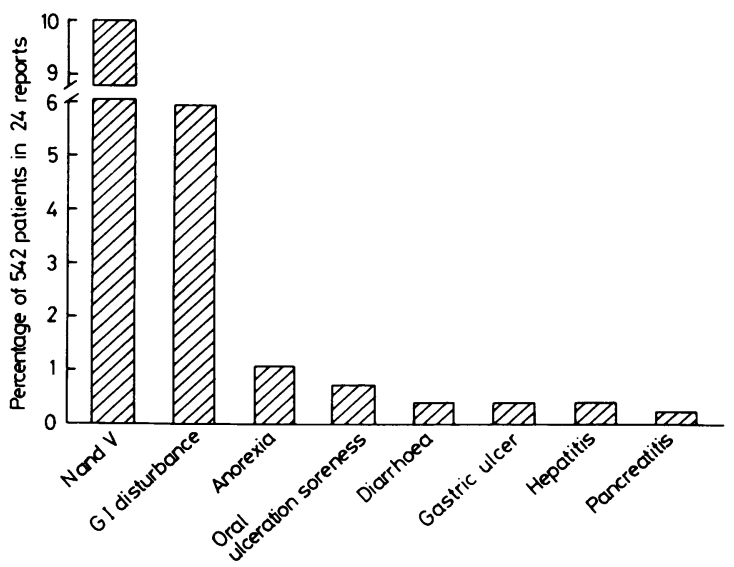

FIG 2 Incidence of gastrointestinal adverse effects reported in 24 published reports of 542 patients receiving azathioprine. tabulated from the literature. The occurrence of multiple blood count abnormalities in one patient was confirmed in these reviews. The study by Levy et al, ${ }^{123}$ in which a higher mean dose of azathioprine $(2.9$ $\mathrm{mg} / \mathrm{kg} /$ day) was used, included a relatively high incidence of leucopenia. A patient's disease activity measurements did not correlate with the degree of leucopenia.

Gastrointestinal complaints were reported 103 times in the 542 patients, an incidence of $19 \%$ (fig 2 ). Approximately $10 \%$ of patients had nausea and /or vomiting, and gastrointestinal symptoms, not otherwise specified, were reported in $6 \%$ of patients. Other symptomatology was reported in less than $1 \%$ of the total for each of the following: anorexia six cases, ulceration four cases, diarrhoea two cases and ulcer two cases. Two gastrointestinal toxicities, reported in other investigational uses of azathioprine, were not found in a significant percentage in this review. There were only two reports of hepatotoxicity, a significant problem in the use of azathioprine in renal transplantation. There was only one report of idiosyncratic, or 'allergic', pancreatitis which has been reported in inflammatory bowel disease treated with azathioprine.

The review paid particular attention to patient $\delta$ withdrawal and to prohibitive or life-threatening reactions reported by the authors. Interruption of azathioprine treatment, or withdrawal of patients, was mentioned in relation to both haematological and gastrointestinal toxicity. Eighty-one patients were withdrawn because of drug-related adverse reactions $(15 \%)$.

Reports of infection $(2.4 \%)$ in the context of this immunosuppressive therapy were lower than might have been expected, with most of these being bacterial infection of a non-threatening nature. Five patients, in three reports published before 1970, died

TABLE 2 Deaths or neoplasia reported in seven patients

\begin{tabular}{|c|c|c|c|c|c|c|c|}
\hline Reference & Diagnosis & Sex & Age & $\begin{array}{l}\text { Azathioprine } \\
\text { (mg/day) }\end{array}$ & Duration & Cause of death & Comment \\
\hline Denman et $a l^{45}$ & $\begin{array}{l}\text { Rheumatoid } \\
\text { arthritis } \\
\text { neuropathy }\end{array}$ & $F$ & 66 & 100 & 12 weeks & $\begin{array}{l}\text { Bone marrow } \\
\text { suppression }\end{array}$ & Chlorambucil \\
\hline Lorenzen et $a l^{129}$ & $\begin{array}{l}\text { Rheumatoid } \\
\text { arthritis }\end{array}$ & - & - & - & Few weeks & Pancytopenia & Prednisone \\
\hline \multirow[t]{4}{*}{ Tausch $e t a l^{212}$} & Polyarthritis & - & - & 50 & 7 weeks & $\begin{array}{l}\text { Amyloid } \\
\text { nephritis }\end{array}$ & $\begin{array}{l}\text { Pre-existing } \\
\text { disease }\end{array}$ \\
\hline & Polyarthritis & - & - & 50 & 8 weeks & $\begin{array}{l}\text { Amyloid } \\
\text { nephritis }\end{array}$ & $\begin{array}{l}\text { Pre-existing } \\
\text { disease }\end{array}$ \\
\hline & Polyarthritis & - & - & 50 & 18 weeks & $\begin{array}{l}\text { Interstitial } \\
\text { pyelonephritis }\end{array}$ & $\begin{array}{l}\text { Pre-existing } \\
\text { disease }\end{array}$ \\
\hline & & & & & & Site of neoplasm & \\
\hline Cade $e t a l^{25}$ & $\begin{array}{l}\text { Rheumatoid } \\
\text { arthritis }\end{array}$ & $F$ & 44 & 75 & 4 years & $\begin{array}{l}\text { Carcinoma of } \\
\text { the cervix }\end{array}$ & \\
\hline Pinals $^{177}$ & $\begin{array}{l}\text { Rheumatoid } \\
\text { arthritis }\end{array}$ & $\mathrm{F}$ & 59 & 100 & 9 months & Lung carcinoma & Prednisone \\
\hline
\end{tabular}


during treatment. ${ }^{45129212}$ These five patients, plus two who developed malignancy, are summarised in table 2 . The three patients reported by Tausch $e t a^{212}$ had renal dysfunction before immunosuppressive therapy, and it is doubtful that their deaths during treatment were caused by the drug.

The special concern about the induction of neoplasia in patients receiving this immunosuppressive thiopurine is the subject of other presentations in these proceedings. While we are aware of 18 individual case reports of malignancy in RA patients who have received azathioprine, the total number of patients treated is unknown. This review of 542 patients from 24 studies identified only two cases of carcinoma, an incidence of $0.4 \%$. This may be compared with estimates of 0.6 to $2.6 \%$ malignancy in all patients with RA.

\section{Discussion}

The total frequency of adverse reactions in patients with RA treated with azathioprine compares favour- ably to the incidence of toxicity with other slowacting, remission inducing agents. Physicians report unacceptable side-effects, or significant toxicities requiring withdrawal, in a significant percentage of patients and $1 \%$ of patients may develop lifethreatening toxicity.

The six studies published in 1976 to $1977^{1218255680177}$ show a lower incidence of leucopenia of $10 \%$, and new treatment programmes are designed to follow recommendations for using lower doses of azathioprine (1.0 to a maximum of 2.5 $\mathrm{mg} / \mathrm{kg} /$ day). Investigators have suggested temporary interruption of treatment, until white blood cell counts return to normal, and perhaps restarting the drug at half dosage. Dose modifications for controlling white counts, in patients taking 6-mercaptopurine or 6-thioguanine, are well known. However, in contrast to the treatment of malignant diseases, intentional suppression of peripheral leucocyte counts by progressive increase in dose is not considered to be the critical determinant of therapeutic response in RA. 